\title{
Naval Forces and Civil-Military Relations
}

\author{
Tobias Böhmelt, ${ }^{1}$ Ulrich Pilster, ${ }^{2}$ and Atsushi Tago ${ }^{3}$ \\ ${ }^{1}$ University of Essex and ETH Zurich, ${ }^{2}$ University of Essex, and ${ }^{3}$ Kobe University
}

\begin{abstract}
While the importance of navies for international affairs is widely documented, their influence in domestic politics remains less well understood. This research offers the first comparative account of how states' naval forces affect civil-military relations. Does the navy matter for military attempts to seize government power? The urban population and, especially, middle class elements in the capital city are potentially more capable (if willing) to create the conditions for the armed forces to overthrow the government. Because naval forces are more strongly linked to these societal elements due to recruitment practice and the location of their bases, countries with a larger navy in relation to the army could be more likely to see coups d'état. The empirical findings, based on the analysis of time-series cross-section data on a sample of all states between 1970 and 2007, provide strong support for the theory. Several robustness checks further increase the confidence in the results.
\end{abstract}

Key words: civil-military relations, coup d'état, naval forces

Address correspondence to: Tobias Böhmelt, Department of Government, University of Essex, Wivenhoe Park, Colchester CO4 3SQ, United Kingdom; E-mail: tbohmelt@essex.ac.uk; Tel.: + 4401206872288.

Note: A version of this paper has been presented at the "Kobe Sakura Meeting 2015" (International Conference for Collaborative Research in International Relations and Comparative Politics, Kobe, JP, April 8-10, 2015), the conference "Institutions of Protection: The Organization of Security and Justice System Institutions in Autocracies" (Madrid, ES, June 18-19, 2015), the Academic Study Group Research Workshop (Haifa, IL, November 5-6, 2015), and the $57^{\text {th }}$ Annual Meeting of the International Studies Association (Atlanta, GA, 16-19 March, 2016). The Suntory Foundation and the Daiwa Anglo-Japanese Foundation financially supported this research. We thank Barış Arı, Alex Braithwaite, Abel Escribà-Folch, Erik Gartzke, Vincenzo Bove, Cath Collins, Brad Epperly, Jessica Maves-Braithwaite, Tom Ginsburg, James Lee Ray, Julio Ríos, Andrea Ruggeri, Jaqueline Sievert, Jeffrey Staton, Milan Svolik, Joseph Wright, the journal's editor-in-chief, Deborah Avant, and the anonymous reviewers for helpful comments and suggestions. 


\section{Introduction}

The ruling elite of the Ottoman Empire constantly feared the overthrow by their naval forces: the $34^{\text {th }}$ Ottoman Sultan, Abdul Hamid II, ensured that "the navy was not allowed to leave its docks in the Golden Horn for fear it might train its guns on the palace [...]. The sultan was well aware of the liberal leanings of many of the graduates from the great military colleges" (Zürcher 2004, 80; see also Uyaar and Erickson 2009). In Portugal, moreover, naval forces led the revolution in 1910, which resulted in the downfall of the monarchy and the establishment of the republic, and sailors of the German High Seas Fleet staged the Kiel Mutiny in November 1918, leading to the November Revolution in Weimar Germany. More recently, over the last 50 years, naval officers have been prominently involved in planning and/or directly conducting coups in, among others, Thailand, Guinea Bissau, Argentina, Chile, or Venezuela.

Despite plentiful anecdotal evidence, however, there is a lack of systematic research on the role of naval forces in domestic politics and, in particular, civil-military relations and coup attempts (for important exceptions, see Heginbotham 2002; 2004). From a policy perspective, this might be a concern due to at least two reasons. On one hand, various regional and emergent global powers have embarked on ambitious programs of naval modernization, which are likely to increase the political importance of navies within their respective militaries. This includes most prominently China, but also various South-East and East Asian states, such as Thailand or Vietnam; India and Pakistan in the Indian Ocean; Algeria, Egypt, or Turkey in the Mediterranean region; and Saudi Arabia and the United Arab Emirates in the Persian Gulf. Not all of those states have a history of stable civil-military relations.

On the other hand, military coups remain a very contemporaneous phenomenon in world affairs. Important regional powers such as Egypt and Thailand have witnessed military coups over the last years. The data on governmental overthrows by Powell and Thyne (2011) highlight that there have been 475 such coup attempts (successful and unsuccessful) between 1950 and 2016. Commonly, coups not only have crucial implications at home, but also affect outcomes well beyond a country's 
border (see Goldsworthy 1980; Janowitz 1977; Feaver 1992; Quinlivan 1999; Belkin 2005; Roessler 2011; Powell 2014; Thyne and Powell 2014; Thyne 2015): the downfall of governments, democratization, economic recession, increased military spending, genocide, or civil wars and domestic/regional instability are just a few of these domestic-level and international consequences.

Therefore, it is important to understand the determinants of military attempts to seize power, ${ }^{1}$ and the factors driving stability or instability of civil-military relations as such. Numerous studies on these issues are usually bundled along two different, yet interrelated clusters (e.g., Luttwak 1968; Thompson 1973; Quinlivan 1999; Powell and Thyne 2011; Pilster and Böhmelt 2011; 2012; Powell 2012; 2014; Harkness 2016; Hiroi and Omori 2013; Singh 2014; Arbatli and Arbatli 2016; Böhmelt and Pilster 2015; Girod 2015; McMahon and Slantchev 2015; Piplani and Talmadge 2016). First, there are the characteristics of and factors related to the military itself. Second, there is the sociopolitical environment in which a state's armed forces exist. This includes determinants such as regime type, governmental stability, income, economic growth, or previous coup history.

The following article seeks to bring together these two clusters by showing how a feature of the military, the relative strength of the naval forces, interacts with one aspect of the socio-political environment, the urban population, in order to explain the likelihood of a coup. We contend that the urban population and, particularly, the middle class elements in the capital city represent a social segment that is more capable if willing of creating the opportunity for the military to overthrow the government; that is, if members of the middle class are motivated to prompt a coup (willingness), concentration in the capital increases their capability to do so (see Huntington 1968; Wallace 2013; 2014). By their recruitment practice and location of their bases, naval forces are especially likely to be strongly linked to and take up the political demands of these social elements. Correspondingly, the beliefs and interests of the urban population and, mainly, middle class elements in the capital city affect military positioning more strongly toward politics in those countries where navies are

1 Generally, Luttwak $(1968,27)$ defines a coup as "the infiltration of a small, but critical, segment of the state apparatus, which is then used to displace the government from its control of the remainder." 
relatively larger than other branches of the military, principally the army (Heginbotham 2002; 2004). Ultimately, coup risk could be likely to increase with a stronger navy. ${ }^{2}$

Clearly, we do not suggest that all naval troops and officers will engage in a coup at some point. Our argument is not a deterministic one, and we only claim that naval forces may increase the risk of a coup, all else equal. Having said that, the vast majority of the world's naval forces never directly engages in overthrowing their governments, and most countries that have a navy will not experience any coup attempt at all. Analogous to the literature on refugees and the onset of civil war (e.g., Saleyhan and Gleditsch 2006), this should not make us ignore, however, the possible implications that naval forces have for civil-military relations and domestic security effects more generally. ${ }^{3}$

The next section outlines our motivation for this study, and demonstrates where and how we intend to contribute to existing work. We then develop our theoretical argument in three parts. First, we show how coups evolve and describe the role of military-civilian coalitions. Second, we contend that the urban population and, especially, middle class elements in the capital city have a special role in this regard. Third, we link naval recruitment to these social segments, which leads to the claim that larger navies (in relation to the army) are more likely to be associated with coup attempts. We illustrate the main parts of our argument with anecdotal evidence, while the 1973 coup in Chile is discussed separately as a theory-building illustrative case. Afterwards, we present our research design, focusing on the data, the variables, and the estimation procedure. We then discuss our findings and conclude the article by outlining policy implications and avenues for further research.

2 The assumption behind this, and our empirical operationalization of the variable on naval forces, is that troop/branch size translates into actual power and influence. In addition, note that our statistical models address associations between variables, not causation. We return to this in the conclusion

3 As Saleyhan and Gleditsch $(2006,339)$ state, "[t]he vast majority of the world's refugees never directly engage in political violence but are rather the unfortunate victims of it. Furthermore, most refugee hosts never experience armed violence. Nevertheless, this alone should not lead scholars and practitioners to neglect the possible security consequences that often accompany refugee flows." 


\section{Why Studying the Role of the Navy in Domestic Politics?}

\section{Motivation and Contribution}

Focusing on the navy might come across surprising, since it is often assumed that only the army, or a faction thereof, has the capacity to actually stage a coup as it is the only branch with the necessary ground-combat manpower (e.g., Janowitz 1964, 32f; Luttwak 1968, 61). The navy, on the other hand, has mainly been neglected when studying coups attempts (see also Heginbotham 2004). As Pilster and Böhmelt $(2012,360)$ outline, "the weapon systems typically employed by navies [...] are only of limited suitability in the tactical activities entailed by the conduct or prevention of a coup." " But are naval forces that irrelevant for explaining coups and, by extension, civil-military relations in general?

As indicated above, contrary to the scholarly work suggesting that navies are unlikely to matter, there is plenty of anecdotal evidence emphasizing the opposite. We ultimately face a puzzle in light of these cases: previous academic literature tells us little about the involvement of the navy in coups and civil-military relations; it sometimes even rejects any direct influence, but existing anecdotal evidence suggests that the navy's role might have been - and remains to be - very much decisive. For shedding more light on this, we offer the first systematic theoretical and empirical study linking a state's naval forces to civil-military relations and, particularly, coup attempts.

The findings we present have important implications for our understanding of coups d'état and, in general terms, civil-military relations. We seek to contribute to the growing literature on the impact of a country's security-force structure on civil-military relations and contentious politics (e.g., Lyall and Wilson 2009; Sechser and Saunders 2011; Powell 2012; 2014; Caverley and Sechser 2016). Huntington $(1968,193 f)$ argued that it "is [...] fallacious to attempt to explain military interventions in politics primarily by reference to the internal structure of the military [...]. Military explanations do not explain military interventions." Recent research, however, demonstrates that this is unlikely to hold; on the contrary, there is a necessity "to bring the military 
back into the study of military intervention [...]. Military actors are ignored too frequently" (Singh 2014, 78; see also Powell 2012; Böhmelt and Pilster 2015). Our research is one of the first that points to the importance of a state's naval forces for a coup, while simultaneously accounting for the socio-political environment in which the armed forces exist. To this end, our work constitutes a major departure from the previous, "traditionalist" view stating that navies are unlikely to matter for overthrowing the government or intervening in civil-military relations.

Hence, we also provide a complement to international relations research, where the role of naval forces in international politics has traditionally received significant attention, with navies seen as a vital element "to project influence and to protect their [states'] interests across the world's waterways" (Crisher and Souva 2014, 602; see also Mahan 1890; Fordham 1998; 2004; Modelski and Thompson 1988; Thompson 1976; Heginbotham 2002).

\section{How Do Coups Emerge? Willingness, Opportunity, and Popular Support}

Coups are usually determined by and evolve through the opportunity and willingness of particular, sufficiently strong segments of the society to overthrow a government (Hibbs 1973; Huntington 1968: 192ff; Finer 1988; Luttwak 1968; Decalo 1990; Belkin and Schofer 2003). We assume that a rational cost-benefit calculation underlies these considerations, i.e., the expected benefits of a successful coup must outweigh the costs of planning/conducting it as well as any negative consequences associated with potential failure (Thyne 2010; Powell 2012, 1019; see also Belkin and Schofer 2003, 597).

Only the military has the capacity to actually stage a coup against a government that maintains at least some control over the means of violence (e.g., Huntington 1968, 217). ${ }^{5}$ Nevertheless, the erosion or lack of broader societal support for civilian rule is often seen as a precondition for military interventions in politics. The opportunity for a successful coup only exists if an incumbent

5 As Huntington $(1968,213)$ describes, "riots and demonstrations are a common form of political action by students and related middle-class groups. Typically, such actions bring about the downfall of the government only where they polarize the situation in such a way as to compel the military to oppose the government." 
government is extraordinarily dependent on the armed forces for its survival or if the military's popularity significantly exceeds public support for civilian rule (Finer 1988, 72ff; see also Powell 2012, 1021). Against this background, two ideal types of coup-attempt scenarios, which differ in their alliances between the military and the civilian population, are imaginable (see Magaloni and Wallace 2008; Casper and Tyson 2014; Singh 2014) in what Huntington (1968; see also Perlmutter 1969) calls "praetorian societies."6

First, unrest increases among segments of the civilian population, who signal their willingness to support the military staging a coup against the ruling elite. These signals can be sent in the form of private communication with military officers, often in the context of escalating public protests and political confrontation. In turn, the military may eventually back the civilian protest and overthrow the government (Welch 1970, 32; Stepan 1974, 93ff). In this first scenario, civilian forces, thus, escalate social conflict first to such a degree where military intervention becomes likely (see Huntington 1968, 208-219), and then a coup is the product of a coalition of civilian and military groups.

A second scenario refers to coups originating within the military due to, for example, lower military expenditure, the conversion toward more civilian politics, or a general dissatisfaction with the present decision-making of the political elites (Nordlinger 1977; see also Svolik 2012). Under these circumstances, popular support may not be secured initially. That said, gaining the support of the (wider) civilian population is still essential, since this will increase the expected chances of success for the coup and the ensuing period of military rule. ${ }^{7}$ For instance, the failure of the

6 A "modern praetorian state is one in which the military tends to intervene and potentially could dominate the political system" (Perlmutter 1969, 383; see also Huntington 1968, 195ff). Also note that the two ideal types of coup-attempt scenarios apply to all three of Huntington's (1969) coup types: breakthrough coups, guardian coups, and veto coups.

7 Singh's seminal work (2014) treats coups as coordination games taking place entirely within the military, with popular support neither influencing the probability of a coup attempt nor its chances of success. While we agree with Singh's conceptual model, we believe that he may overstate his case against the importance of the positioning of civil society. This is, for instance, illustrated by a statement of Brazilian General Golbery do Couto e Silva, who had been a key actor in various coup attempts in the 1960s (cited by Stepan 1971, 97): "[m]lilitary activists for or against the government are always a minority. If a military coup wants to overthrow a government, they need to convince the great majority of officers who are either strict legalists or simply non-activists. Activists do not wish to risk bloodshed or military splits, so they wait 
September 2015 coup attempt by the presidential guard in Burkina Faso has been attributed to popular protests that erupted in response and signaled "that the [...] the presidential guard [...] did not have control over the vast majority of the country and would not be able to rule for long"

(Allisson 2015). Four days after the coup attempt, against the background of popular protests and international condemnation, leaders of the regular Burkinabe army announced that their troops were marching toward the capital in order to reinstate the deposed government of President Michel Kafando. The 2016 coup attempt in Turkey further illustrates our claim on the need for public support. Coalitions between civilian and military segments are, therefore, of central importance for conducting a coup, regardless of whether civilian or military forces are the initial driving force behind it. ${ }^{8}$ Conversely, if a coalition between the military and the civilian population does not emerge as, for example, the military seeks order and represses mobilization, it is unlikely that a coup will emerge.

\section{The Role of the Urban Population in the Capital, Especially the Middle Class}

However, not all societies are created equal and countries simply differ in their coup risk as they vary across political, economic, and demographic characteristics. Ultimately, the structure and composition of the society affect the likelihood of a coup by determining the possibility that a civilian-military alliance wanting to overthrow the government emerges (Huntington 1968, 194f). Following Huntington (1968) or Wallace (2013), we argue that the urban population and, especially, middle class elements in the capital city are likely to be the critical element here: if members of the middle class are motivated to prompt a coup (willingness), concentration in the capital increases their capability to do so. We focus on the capital city's share of the total urban population of a country in order to operationalize this (described in the research design). Wallace

until a consensus has developed. Thus movements to overthrow a president need public opinion to help convince the military itself."

8 The implication follows that the incumbent also needs the population's support for preventing a coup (Casper and Tyson 2014; Svolik 2012; Bueno de Mesquita et al. 2004; Wintrobe 1998; Luttwak 1968). Lowering the willingness and opportunity for a coup depends on successful governance. 
(2013) demonstrates how "urban concentration," i.e., the concentration of a country's urban population in its capital city, is a major source of instability and could threaten regime survival, predominantly in developing countries (see also Wallace 2014; Perlmutter 1969, 386; Hobsbawm 1973; Zipf 1941). In fact, he claims that states with a higher degree of urban concentration are more likely to suffer from "praetorian politics" (Wallace 2013, 634; Huntington 1968). The argument underlying the link between urban population and civil unrest is that cities "increase the ability of private grievances to accumulate and circulate" (Wallace 2013, 632). This is because urban populations comprise large masses of people in concentrated areas, who will find it easier than the rural population to overcome problems of political collective action due to facilitated communication flows. ${ }^{9}$ The grievances of the urban population become especially politically salient once they are expressed in capital cities, due to "the proximity of the population to the center of power and commerce" (Wallace 2014, 22).

Among the various segments of the urban population, especially in a country's capital city with their heightened capacities for collective action, it is usually the urban middle class - i.e., individuals with an above-average education, making a living as government or private sector employees, merchants, professionals, or owners of small- and medium-sized enterprises - that is likely to organize protests demanding the overthrow of a government. On one hand, as long as the urban middle class is politically disenfranchised, its self-ascribed ideals of efficiency, economic, and social reform often pull it into opposition to an oligarchic ruling class perceived as corrupt and backward (Huntington 1968, 201). Surveys conducted in the aftermath of 2011's "Arab Spring," for example, indicate that the urban middle class dominated the anti-regime movement in Egypt and

9 A possible objection to this claim is that it is also easier for the government to coordinate repression in urban areas. The literature (e.g., Toft 2003) indeed focuses on the argument that governmental repression is more likely (and more likely to be effective) in those areas under governmental control which are mostly urban areas. However, as discussed in Staniland (2010) and other works (e.g., Urdal and Hoelscher 2012; Wallace 2013; 2014; Beall et al. 2013; Moncada 2013) urban social mobilization is not only possible, but also very frequent - and this is precisely the claim that we draw on here. Mobilization, as facilitated by overcoming the associated collective action problem, can provide a social base for insurgency "in areas that prevailing theories deem unlikely sites of civil war" (Staniland 2010, 1623). We also discuss a robustness check in the appendix that directly controls for the level of governmental repression. 
was disproportionately represented in the Tunisian protests. The most important reasons for participating in these protests were demands for an improved economic situation and for combatting the corruption pervasive in public institutions (Beissinger et al. 2015).

On the other hand, "once middle-class urban groups become the dominant elements in politics, [...] they become engaged in a conservative effort to protect the existing system against the incursions of the lower class" (Huntington 1968, 222; see also 219ff). Under these circumstances, opposition against the government is often triggered by "populist" policies redistributing political power and economic resources to the urban lower and working classes as well as the rural population. This is illustrated by the two military coups in Thailand (2006 and 2014, respectively). Both occurred in the context of political impasse, brought about by the conflict between a Bangkokbased urban middle class and two governments led by members of the Shinawatra family implementing redistributive policies in favor of rural constituents. The urban middle class's major grievance has been described as the loss of the "prestige and wealth [it had gained] from its association with the monarchy and decades of royalist-driven capitalist development in the capital" (Unaldi 2014).

In short, the grievances of the urban population and, especially, middle class elements in the capital city can play a decisive role in various coup types, be it breakthrough coups that bring the middle class into power, guardian coups, and veto coups that preserve the middle class's power position. That is, if members of the middle class are motivated to stage a putsch, concentration in the capital raises their ability to actually do so (Wallace 2013; 2014). However, even if elements of the urban population and, particularly, middle class elements in the capital openly have and express their grievances against a government perceived as illegitimate, and even if urban concentration facilitates launching a coup, they still lack the necessary means to overthrow it on their own. An 
alliance with the armed forces is, hence, still necessary if there is to be a coup (see Huntington $1968,201)^{10}$

\section{The Impact of Naval Forces on Coups}

Under which conditions are potential demands of the urban population (and, especially, middle class elements) in the capital city more likely to be taken up by elements within the armed forces?

We assume that plotting and conducting a coup is a complex, frequently clandestine process of coalition-building, involving both elements of the armed forces and politically mobilized segments of the civil society (Stepan 1971, 73ff). ${ }^{11}$ The military cannot be conceptualized as a unitary actor, however. Instead, different cliques of officers have diverse political preferences, also of a domestic kind. Service background is one important determinant of officers' political positioning here, "reflected both in the services' activities and the rhetoric of their officers" (Heginbotham 2004, 16, 69ff). We argue that naval officers are more likely to adopt the potential demands and grievances of the urban population and, in particular, the middle class in the capital than their counterparts in the army or air force. ${ }^{12}$ The possibly politically destabilizing interests of the urban population in the capital thus play a stronger role in influencing military positioning toward politics in countries where navies are larger relative to other branches.

10 Note that other ways to oppose the government do exist as well, e.g., (non-violent) mass protests, riots, or demonstrations, which do not necessarily require an alliance with the military. Hence, our claim here only refers to a potential coup attempt, for which such an alliance is needed.

11 With regard to praetorian societies, Huntington $(1968,201)$ states that the "middle-class officers $[\ldots]$ become more and more disgusted with the corruption, incompetence, and passivity of the ruling oligarchy. In due course, the officers and their civilian allies form themselves into cliques and secret societies to discuss the future of their nation and to plot the overthrow of its rulers."

12 In the following, we mainly focus on the distinction between armies and navies. However, there are also important differences between the navy and the air force, which further underline our focus on naval forces and not air forces. Most importantly, Heginbotham (2004, 12-13) states that "aircraft are of modern origin and, even in the militaries of the great powers, air forces were confined within army air corps until long after that. Air forces are, in other words, of much more recent origin than navies. Until recently, the senior officer corps of many air forces had been educated in army academies and should therefore be expected to hold world views less divergent from their army classmates. We should, however, expect to find the political values of air force officers converge with those of the navy within two or three decades of their institutional independence from the army." Put differently, air forces are of more recent origin than navies and often borne out of the army. It then remains unclear whether recruitment and location of bases provide them with a similar affinity to the urban population and, especially, middle class elements in the capital as in the case of the navy. We return to this in the conclusion. 
First, navies are due to their recruitment socially closer to the urban population and the middle class in the capital, while armies are usually more representative of a country's rural areas. This makes naval officers easier points of contact for elements of the urban population and middle class in the capital dissatisfied with the political status quo. In fact, navy "officers tend to come from relatively higher-income families and that more come from urban areas than is the case in the army" (Heginbotham 2004, 78; Brown 1980; 1974, 254). Heginbotham (2004, $11 \mathrm{ff})$ contends that this is due to the "more technical character" of the navy. That is, the navy primarily relies on high-tech equipment and has high technical requirements of operating weapons, and much more so than the army. The former is, therefore, in need of relatively skilled and technically trained personnel (Heginbotham 2004, 78). As a result, navies in developing states may draw the bulk of their officers from their own service academies. Due to the more technical education they offer, naval academies usually have higher academic entry standards than army academies. This privileges applicants from the urban population and, especially, middle class elements in the capital city, which enjoy better access to educational facilities. Moreover, only a minority of army officers is recruited via service academies; most come from the army's enlisted personnel and conscripts, who tend to be mostly from a rural background (Heginbotham 2004, 78f). This kind of social composition is evident in Brown's $(1974 ; 1980)$ study of military recruitment in Greece between 1916 and 1975. The Greek navy is shown to be significantly more likely to recruit from urban areas, with about $40 \%$ of Greek naval cadets in 1974 coming from Athens alone, while only 13\% of the army cadets stemmed from the capital. Moreover, naval cadets were more likely to come from middle-class families than army cadets. The fathers of about $39 \%$ of army cadets in 1974 were farmers; this applied to only $15 \%$ of naval cadets.

Second, the location of bases also matters for which kind of grievances military officers are likely to consider in their decision on whether to seek intervention in politics. The establishment of a civilian-military coalition between elements of the urban population and the middle class of the capital and naval officers is furthered by physical proximity. As argued in Stepan's study of the 
Brazilian military $(1971,94)$, an "exceedingly important [communication channel between civilians and military officers] is provided by the structure and function of the military bases $[\ldots][\mathrm{m}]$ any commanding officers $[\ldots]$ spend much of their time receiving civilian groups at the $[\ldots]$ base or attending civilian gatherings." Army bases are usually located in the rural hinterland, which allows for undisturbed training grounds for the armored forces and where armies have often traditionally been deployed in order to prevent rural unrest. Naval forces, on the contrary, are based in coastal, typically urban areas, due to their need to access harbors and repair facilities (Heginbotham 2004: 80). As a result, naval officers are more likely to be exposed to the potential grievances of the urban middle class, while duty tours in the country interior help sensitize army officers for the plight of the rural population (see also Stepan 1971,95$).{ }^{13}$

In sum, due to both recruitment patterns and the location of their bases, naval officers are more likely to adopt the potential demands and grievances of the urban population and, especially, middle class elements in the capital city than their counterparts in the army or air force. This allows us to formulate the following hypothesis:

Navy-Coup Hypothesis (Unconditional): The larger the size of the navy in relation to a country's army, the higher the likelihood of a coup d'état.

We also test a conditional hypothesis. Our theoretical argument assumes an interactive relationship between the relative strength of the naval forces and the existence of the urban population in the capital city to explain the likelihood of coup. The previous hypothesis implicitly

13 It has also been suggested that naval forces may actually be less likely to engage in military coups due to their relatively higher international exposure in the form of joint exercises and operations, instilling liberal norms in them not to engage in a coup d'état. The empirical literature on the effects of foreign exposure on armed forces' coup proclivity remains divided, though. Savage and Caverley (2015), for instance, demonstrate that US-provided military training increased the likelihood of coups in a sample of 189 countries from 1970-2009. Ruby and Gibler (2010), on the other hand, show that US foreign officer training may have contributed to a reduction in coups d'état abroad. Moreover, there are also examples of how the influence of values acquired by naval officers interacting with Western counterparts does, in fact, increase the likelihood of a coup: Reiter $(2001,58)$ and Porch $(1977)$ focus on the Portuguese Navy and argue that the exposure to NATO made Navy personnel to open "their eyes to the flaws in Salazar's dictatorship," which eventually contributed to the Portuguese Navy backing the military coup in 1974. 
assumes that a sufficiently sized urban population (and middle class) in the capital are present. This may, however, not be the case in all countries (see also Huntington 1968, 220), and we therefore directly incorporate the claim that if the middle class is motivated to prompt a coup, urban concentration enhances their capability to do so. We thus also formulate the following, conditional hypothesis:

Navy-Coup Hypothesis (Conditional): Given the presence of a sufficiently large urban population in the capital, the larger the size of the navy in relation to a country's army, the higher the likelihood of a coup d'état.

Before coming to the Chile case illustration and the quantitative-empirical analysis of our research, we discuss the possible objection to our argumentation that naval forces, due to their type of weapon systems and sea-bound character, do not possess the capacity (opportunity) to intervene in domestic politics or conduct a coup. This is usually based on the assumption that naval weapon systems, especially the naval artillery of the surface fleet, are of little use in the tactical activities most typical of a coup, such as the seizure of public buildings or the arrest or execution of key officials. However, this common assumption does not entirely hold up to empirical scrutiny. It is, indeed, the case that infantry forces are of essential importance in overthrowing a government, which results in army formations normally having an important, if not the leading, role in the conduct of a coup (see also Singh 2014, 86). Nevertheless, there are a variety of mechanisms through which naval forces can influence coups.

First, naval officers may take the lead in the planning of a coup up to the point of them becoming the "most committed element" (Heginbotham 2004, 36, 45-48). Second, a significant number of naval forces worldwide also dispose of infantry in the form of marine forces, which they may use for a coup. The abortive June 1955 coup against the Peron government in Argentina was planned by Rear Admiral Toranzo Calderon, the chief of staff of the Argentinian navy's marine corps. The 
coup itself saw the bombardment of the presidential palace ("Casa Rosada") in Buenos Aires by naval aviation, before a battalion of marines seized the naval headquarters and tried to capture it. The coup attempt ended after the surrender of the marine battalion to pro-Peron army formations (Scheina 2003). ${ }^{14}$

Third, coups entail more than "battles on the ground" to seize key public installations. Instead, a coup can be best understood as a bargaining game in the shadow of civil war, which is about the expectations of various parts of the armed forces that share a joint interest in preserving military unity and avoiding fratricidal civil war (Singh 2014). Naval weapon systems with their potential to perpetrate large-scale direct violence in coastal areas can play a significant role in this bargaining game. The success of the September 1955 coup attempt in Argentina was largely due to the credibility of the threat of the naval fleet controlling Buenos Aires' sea lanes to bombard the capital: "[t]he rebel radio demanded that Peron surrender [...]. [F]ailure to comply would result in the bombardment of Buenos Aires. The radio described in full detail the capability of the fleet's guns, which was substantial" (Scheina 2003). Naval fires directed against formations that had not joined the rebels, such as the pro-Peron air force's anti-aircraft school, further underlined the credibility of the threat to bombard the capital. This ultimately led to pro-Peronist forces surrendering and the president resigning on September 19, 1955 (Scheina 2003).

Finally, the internal cohesion of navies acts as a force multiplier for its role as a domestic political player. Military organizations are most effective in intervening in politics when they are not divided (Janowitz 1977; Huntington 1968, 214; Heginbotham 2004, 15, 44, 79). ${ }^{15}$ Naval officers and enlisted personnel have a stronger sense of service tradition and cohesion than their counter-parts in the army or air force. This is due to a more homogenous professional socialization,

14 We also return to the case of naval infantry in the appendix.

15 Heginbotham $(2004,69)$ writes, for example, that "the degree of internal unity and cohesion of each service's officer corps, in terms of political outlook, will depend on the degree of homogeneity in the composition and organization of subordinate units and officers [...]. The navy's officer corps, being more homogenous in this dimension, will tend to be more united than that of the army." 
including academy training and technical assignments early on in their careers. ${ }^{16}$ Trinkunas' (2006, 88ff) work on the Venezuelan Navy in the 1950s illustrates the domestic political capabilities naval forces might possess: "[w] hile the navy lacked the heavy land-based weaponry of the army and the strategic positions of the army's garrison in Caracas, it was able to provide a deterrence force through its marine infantry battalions and the guns of its destroyers, based 12 miles away in La Guaira. The very cohesiveness of the navy, in an otherwise incoherent military, made it more powerful than its capacities alone would suggest."

\section{The September 1973 Coup in Chile as a Case Illustration}

While it is beyond the scope of this article and we lack the space to present a comprehensive and detailed qualitative case study on all components and the main mechanism of the theory, we briefly illustrate the 1973 coup in Chile as we believe it plays an important role as a demonstration that the mechanism we hypothesize has indeed occurred. This case illustration stresses our main theoretical points in the context of a narrative and clarifies our argument. First, our theory rests on the assumption that coups emerge out of an alliance between the military and the civilian population. In the first of the two possible scenarios, civilian forces escalate social conflict to such a degree where military intervention may become likely (see Huntington 1968, 208-219). A coup is then the product of a coalition of civilian and military groups. And, in fact, this process occurred before the September 1973 coup in Chile. On one hand, there was extensive civilian - particularly middleclass - contact with the naval leadership before the coup attempt. Teichman $(2015,10)$ reports that "most of Chile's middle classes" have become supporters of the Christian Democratic Party by the late 1960s and, in turn, it was that party's leadership that had pressured Allende at first to bring in

16 Navies operate technically sophisticated weapon systems, and rely on officers educated at academies and enlisted personnel who are long-term service volunteers. Moreover, naval staff tends to have assignments on more technical tasks early in their careers. Armies, on the contrary, exhibit a higher degree of variation in the technological sophistication of the functions they fulfill, ranging from almost entirely non-technical infantry tasks to more challenging functions, such as armor or communication. Additionally, in most developing countries, only a minority of army officers shares the joint experience of being academy-trained, with a significant number of line officers being recruited from previously enlisted staff. Instead of long-term service volunteers commonly found in naval forces, conscripts constitute a significant share of the enlisted personnel in armies (Heginbotham 2004, 90ff). 
members of the military into the cabinet and, afterwards, had given its approval to the navy for staging the coup. There is also evidence that especially Vice Admiral José Toribio Merino, who was promoted to the commander of the navy on the day of the coup, attended meetings with members of the Christian Democratic Party. In addition, “[o]ne important lower middle class group that backed the coup and later became instrumental in the development of post-coup economic policies was a group of economics professors at the Catholic University who became known as the "Chicago boys" $[\ldots]$. They were closely allied with big corporate executives in public attacks on Allende's policies, in preparing a replacement economic plan, and in establishing contacts with the navy in preparation for the coup" (Teichman 2015, 11; emphasis added). On the other hand, this putsch was ultimately made possible by the military's impression that Chile was on the brink of economic collapse and civil war. One of the central factors contributing to this were the repeated work stoppages initiated by associations of small and medium-sized enterprises, including truck, microbus and taxi owners, retailers, and middle-class professionals. These strikes, and the Christian Democratic Party was partly involved there as well, were motivated by the fear of the economic consequences of the Allende government's project to establish a socialist society - a fear that ultimately lead to elements in the armed forces plotting a coup (Ensalaco 1999, 17-18; Teichman $2015,11)$.

Second, we contend that if members of the middle class are motivated to prompt a coup, concentration in the capital may raise their ability to do so. However, this part of the argument is linked to the claim that navies are indeed closer to the urban population and, particularly, the middle class elements in the capital city, as such a link would facilitate the establishment of an alliance between the civilian population and the armed forces. Our argument for this partly focused on naval recruitment practice, which makes navies socially closer to the urban population and the middle class in the capital. It has, for instance, been argued that in the run-up to the September 1973 coup in Chile "the navy, whose officers tend to come from more affluent social backgrounds than do 
officers from other branches of the armed forces, had been the first branch of the military targeted by the political Right's campaign for a coup" (Spooner 1999, 33).

Third, even when subscribing to the strong link between the urban population and, mainly, the middle class in the capital, do naval officers play key roles in a coup? We suggest that naval officers can take the lead in planning a coup and may, in fact, be the "most committed element" (Heginbotham 2004, 36, 45-48). With regard to our case illustration, before the 1973 overthrow of the Allende government in Chile, the first inter-service consultations on conducting a military coup were initiated and driven by admirals of the Chilean navy. Especially Merino played a leading role (Spooner 1999, 30ff). As Spooner (1999, 33) concludes, “[t]he Chilean navy’s high command was already actively planning a coup, and any officers suspected of pro-Allende leanings had to be silenced." The arrangements for a coup were finally set in motion by a letter on September 9, 1973, from Merino to the commanders of the army and air force, Generals Pinochet and Leigh, which "asked that the two generals merely sign the missive in order that the Chilean navy put its coup planning in effect. Leigh signed, and after some hesitation so did Pinochet" (Spooner 1999, 37). ${ }^{17}$ Eventually, the "coup began with a predawn uprising by the Chilean navy in the port of Valparaiso" (Spooner 1999, 38). To this end, the navy played a, if not the key, role in plotting the 1973 coup in Chile; it had strong links to urban and, in particular, middle class segments of the society, which facilitated the establishment of a military-civilian alliance; and, finally, the Chilean urban population and middle class had developed a sufficient amount of grievance against the government due to the economic crisis (Spooner 1999, 30-31).

\section{Research Design}

\section{Data and Dependent Variable}

We constructed a monadic time-series cross-sectional data set with the country-year as the unit of analysis. Since some of our variables (that we describe in the following) have only limited data

17 Note, however, that factions of the Chilean Army were also active in the organization of the coup and in its implementation and the succeeding military rule. 
availability, the time period is restricted to 1971-2007. Ultimately, and after accounting for missing values, our final sample comprises 4,408 country-years. Given the binary nature of the dependent variable (described in the next paragraph), we use logistic regression models and include a coupyears variable (i.e., a variable counting the years elapsed since the last coup, if any) and cubic splines (Beck et al. 1998) to control for likely temporal dependencies. Finally, we report robust standard errors clustered by country to correct for potential bias due to non-constant variances.

For our dependent variable, we use Powell and Thyne's (2011) data on coups between 1950 and 2014. A coup attempt is defined as an "attempt by the military or other elites within the state apparatus to unseat the sitting head of government using unconstitutional means" (Powell and Thyne 2011, 249ff). Powell $(2012,1026)$ recoded the data from a count variable per country-year to "a dichotomous measure that considers whether or not at least one attempt was made in that year" (emphasis added). Thus, our dependent variable takes the value of 1 if at least one coup attempt occurred in a specific country-year and 0 otherwise. Out of the 4,408 country-years in our data set, 170 receive the value of $1 .{ }^{18}$

\section{Explanatory Variables}

Our main explanatory variable is the size of the navy relative to the army. The data on a country's navy and army size are taken from the Military Balance (International Institute for Strategic Studies 1970-2014). Based on this information, we calculated the ratio by dividing the size of the naval forces, i.e., their personnel, by the size of the army (army personnel) for each country-year. ${ }^{19}$ This approach also follows Heginbotham (2004, 77; see also 2002, 93ff) who emphasizes the crucial differences between the army and the navy: "(1) the relative importance of capital and technology; (2) the background, education, and experience of their officers; (3) the quantity and quality of the

18 The data do not contain information on who launched a coup due to the lack of coding.

19 However, our results are virtually identical when simply using the size of a country's navy. Also note that the appendix presents robustness checks for dealing with the determinants of navy size more directly. These analyses focus on, inter alia, states' total number of direct contiguities by sea, drop land-locked countries from the sample, and include regional fixed effects. 
enlisted personnel required by each; (4) the location of their bases; and (5) the degree and type of contact that the officers enjoy with their foreign counterparts."

This operationalization mirrors a leverage argument: the larger the size of the navy as compared to the army, the more influence and power it will have compared to this latter branch. And since it is the navy that matters for and establishes the link to the urban population and, most likely, the middle class of the capital, its leverage over the army and within the whole military of a country will be key. Most navies in our data set are smaller than armies and, hence, the measure captures effectively how much smaller the navy is than the army. Still, the basic rationale behind our operationalization seeks to address the leverage aspect. The final variable, Navy Ratio, which ranges in $[0 ; 1]$, is lagged to address endogeneity concerns.

The quality of the Military Balance data has been widely discussed (for an extensive discussion, see, e.g., Pilster and Böhmelt 2012). For instance, earlier editions only focused on the US-USSR rivalry, which induced that a limited number of countries has been covered; a larger share of states is only included as of the 1970s. Also, there are some inconsistencies and possible coding errors, although primarily with regard to paramilitary forces (Belkin 2005, 156; Sechser and Saunders 2010, 491). While the data are thus not perfect, Pilster and Böhmelt (2012) show that there is indeed a substantial degree of consistency. Figure 1 further supports this claim by plotting the median band of Navy Ratio over the time period under study (the interval of its minimum and maximum is used for the vertical axis). If there would be a large degree of bias stemming from, e.g., organizations appearing in the data for years after they were abolished or cases in which they appear and reappear without reason, we simply would not observe such a high degree of consistency over the time period. Additional tables and graphs providing descriptive statistics for Navy Ratio are included in the appendix (Appendix Table 1 and Appendix Figure 1).

Figure 1 here 
Second, for the conditional navy-coup hypothesis, we need an interaction with a proxy for the presence of a sufficiently large urban population and, especially, middle class segments in the capital city. We decided to take Wallace's (2013) item on urban concentration for this. This variable measures the "capital city's share of the total urban population of a country" (Wallace 2013, 638), and is based on the United Nations Population Division's World Urbanization Prospects 2009 Revision. If capital cities have moved over time, this is taken into account by this item. And as Wallace $(2013,638)$ writes, “[u]rban concentration presages political tensions inherent to praetorian politics that undermine regime survival, not only protests themselves but the possibility of protests, the pressure to extract from the periphery in ways that can decimate authoritarian coalitions, the rise of rural dissident groups, and the military inserting itself politically, among others." The variable ranges in $[0 ; 1]$ with a mean value of 0.35 .

\section{Control Variables}

Coming to our control variables, we build upon earlier research (e.g., Powell 2012; Böhmelt and Pilster 2015) and consider a broad set of other alternative determinants of coup attempts as control variables. Most of these controls are not only correlates with the dependent variable and, thus, address the issue of omitted variable bias, but may also influence a country's navy size. That is, we control for observable determinants of our main explanatory variable as well. This latter aspect is particularly important for our empirical models in light of controlling for possible selection problems, i.e., we offer a "selection on observables." 20

First, we control for military regimes (see also Belkin and Schofer 2003; Thyne 2010). Powell (2012: 1028) considers military regimes, since these are frequently associated with a high coup risk. The data on military regimes are taken from Geddes et al. (2014a; 2014b). As discussed in Geddes et al. (2014b), there are currently three main data sources on military regimes. Cheibub et al.'s (2010) data code regimes as military if their leaders wear or have ever worn a uniform. Hadenius

20 The appendix includes a set of additional robustness checks that deviate from these "baseline variables" by including other determinants, also those that more directly influence the size of a country's navy. 
and Teorell (2007) classify autocracies as "pure military" if Banks and Wilson (2012) code the executive as military and the legislature as non-existent or ineffective. Finally, a focus on the rule by the military institution is at the heart of the military-regime definition in Geddes et al. (2014a; 2014b). That is, military regimes are coded when "a group of officers decides who will rule and exercise some influence on policies" (Geddes 2003, 51). The data by Geddes et al. (2014a; 2014b) thus rely on a more restrictive definition of military rule, while Geddes et al. (2014b, 155) highlight that their data set is more appropriate than others when "the purpose of investigating arguments about how the military as an organization or institution affects decision making or autocratic breakdown [...] because it [the data set] limits the regimes coded as military to those in which multiple high-ranking officers influence decision making." In light of this discussion, using the Geddes et al.'s (2014a; 2014b) data seems the most accurate approach, but we provide a robustness check with alternative data in the appendix.

Second, we control for two variables that capture the economic conditions in a country. On one hand, there is Change GDP per capita, which pertains to the percent year-to-year change in GDP per capita. On the other hand, we incorporate the lagged and logged income level per year. Both variables are based on real GDP per capita in 2005 prices. From a theoretical point of view, Powell (2012, 1028) states the underlying mechanism is that good economic conditions induce regime legitimacy, which decreases the risk that there is demand for regime change.

Third, challenges to the regime may not only be affected by economic factors, but also shaped by political influences. To begin with, there is Instability, which captures assassinations, purging of governmental officials, guerrilla activity, protests, riots, and strikes in a country-years (Powell 2012, 1028). We use a lagged and logged variable that is based on Banks (2001). The higher the degree of instability, the stronger is the loss of regime legitimacy. We also incorporate Autocracy and Democracy. These two dichotomous variables capture autocratic and democratic forms of government, respectively; anocracies constitute the baseline category. In general, democracies are less likely than authoritarian regimes to see coups as they are perceived as more legitimate (see also 
Lindberg and Clark 2008). The data for these variables are taken from the Polity IV project (Marshall and Jaggers 2004), while democracies are defined as those countries scoring a value of +6 or higher on the polity 2 scale; in contrast, autocracies are those countries that receive a value of 6 or lower in a specific year. ${ }^{21}$

Fourth, three variables control for the strength of the military: the composition of the armed forces and military grievances as well as professionalism. To this end, Military Personnel, which is logged and lagged by one year, measures the size of a country's armed forces as coded by the Correlates of War Project. As argued in Powell (2012), the larger the military of a country, the less likely a coup will break out. Moreover, a state's expenditure level per soldier (Soldier Quality, lagged and logged) and annual changes therein (Change Military Expenditure) pertain to two related factors: the higher the spending per soldier, the more content and professional is the military. Ultimately, this makes it more likely that the armed forces either respect the status quo (professionalism) or are content with current circumstances (lack of grievances) (Powell 2012, 1027). For these three variables, we thus follow the operationalization in Powell (2012), but use updated versions due to the larger period of time in our data. ${ }^{22}$

Finally, following Böhmelt and Pilster (2015), we include their (Pilster and Böhmelt 2011; 2012) measure of counterbalancing. This variable captures the effective number of ground-combat compatible forces, as these are the only forces whose independent coercive capacities can be used to balance any military unit considering or trying to overthrow a regime. We also take into account the squared term of this variable in our estimations to model the likely curvilinear impact on the

21 When restricting our sample to democracies (and, thus, not including any regime-type variables), our core result for the hypotheses does hold. When restricting the sample to autocracies, the findings for the hypotheses are also unchanged.

22 The first table in the appendix shows that these three variables are not strongly correlated among themselves or with Navy Ratio. Furthermore, note that Powell (2012), although he suggests using this variable, also points out that expenditure per soldier might be a rather abstract proxy for soldier quality in authoritarian states. As demonstrated in the appendix, however, omitting any of the military-related variables does not affect the substance of our findings. 
likelihood of a coup. Both variables, Counterbalancing and Counterbalancing ${ }^{2}$, are lagged by one year. $^{23}$

\section{Empirical Findings}

Table 1 summarizes the main models of our analysis pertaining to the unconditional hypothesis. We present two models that are based on different specifications. The first one focuses on our core variable of interest, Navy Ratio, while we add most controls suggested in, e.g., Powell (2012). In the second model, we add the variables for military regimes and counterbalancing. Given our theoretical rationale, it is particularly important to show that Navy Ratio is not affected by the inclusion or exclusion of Counterbalancing and its square term. ${ }^{24}$

Table 1 here

Models 1 and 2 indicate that there is strong support for our first hypothesis. The larger the size of the navy in relation to the army, the more likely is a coup d'état. The positive and statistically significant coefficient estimates in Models 1-2 back this conclusion. However, as coefficients in non-linear models like the logistic regressions we employ cannot be interpreted directly, we also calculated simulated first difference estimates (King et al. 2000) for Navy Ratio, i.e., the change in the probability of a coup attempt when raising Navy Ratio from its minimum to its maximum while holding all other variables constant at their median values. As Figure 2 demonstrates, while controlling for a large set of alternative influences, the probability of a coup increases by 17 (Model 2) to 22 (Model 1) percentage points if Navy Ratio is increased from 0 (e.g., Rwanda, Luxembourg,

23 Table 1 in the appendix gives an overview of the descriptive statistics of the variables. We also provide a robustness check in the appendix that discards all military-related variables from the analysis. Our findings remain unchanged.

24 It has been suggested that a critical element to consider is whether sea-based infantry operates independently of the command structure of the navy. In the US, for example, the Marine Corps is an independent branch of the military, whereas this is not necessarily true elsewhere. However, since the establishment of an autonomous branch for the marines is a specific coupproofing strategy, we control for this possibility with the Counterbalancing variable, as the coding of this variable takes this directly into account (Pilster and Böhmelt 2011; 2012). 
or Nepal) to 1 (the maximum in the sample underlying the model; e.g., Malaysia in 1993). Similarly, when raising Navy Ratio by one standard deviation (0.15) from its mean value (0.12), the probability of a coup increases by 1.1 percentage points. Both Table 1 and Figure 2 therefore provide robust support for our first (unconditional) hypothesis: the larger a country's navy relative to the army, the more likely is a coup d'état.

Figure 2 here

Coming to the conditional hypothesis, we considered Wallace's (2013) urban concentration item and interacted it with Navy Ratio: the likelihood of a coup with the presence of a larger navy should be more strongly given with a larger urban concentration. The interaction between the Navy Ratio and Wallace's (2013) urban concentration should be positive and statistically significant. Table 2 and Figure 3 summarize our results when considering this multiplicative specification and, thus, the interaction of Navy Ratio and Urban Concentration. These findings suggest that some degree of urban concentration is, in fact, an important requirement for the naval forces to have a positive impact on the likelihood of a coup. In the absence of such a concentration, it is not only less likely that an urban middle class does exist in the capital, but also that the navy can have a positive influence on the risk of a putsch.

Table 2 and Figure 3 here

Note that the appendix discusses additional models that take into account the location of the capital (in-land vs. coastal capital) and the size of naval infantry (in relation to the army). These estimations show, on one hand, that the capital's location is unlikely to influence the overall effect we identify in Table 2. This stresses that the navy may be less involved in executing a coup as such, but can have a significant political role in coups even if it does not dispose of relevant ground- 
combat force. For example, the navy may then focus on playing a political brokerage role between civil society and the other military services. On the other hand, we also report evidence that the size of the naval infantry matters, which shows that when the navy does have ground-combat compatible forces, the risk of a coup attempt increases as navies can then act with less support from other service branches.

In terms of our controls, i.e., alternative determinants of coup attempts and correlates with a country's navy size as identified by earlier work (e.g., Powell 2012; Böhmelt and Pilster 2015), the findings in Tables 1 and 2 confirm earlier results on coups attempts. ${ }^{25}$ Due to space limitations, we briefly discuss the statistically significant findings only. First, democratic regimes are less likely to see a coup attempt. Our calculations of this item's first differences suggest that the risk of a coup is about 1.7 percentage points lower in democracies than anocracies, which constitute our baseline. Note, however, that military regimes data are unlikely to affect coup risk. We return to this in the appendix. A higher level of instability expectedly leads to a higher likelihood of coups d'état, however. On average, coup risk increases by about 3.1 percentage points when raising Instability from its minimum to its maximum value.

Second, while the actual level of income is largely not related to a coup, changes in GDP per capita are. Specifically, increases in GDP per capita and, thus, positive income shocks induce a drop in the risk of a putsch. Across Models 1-3, our results suggest that the likelihood of a coup is about 32 percentage points lower when income has increased by $2.02 \%$ (Kuwait in 1992) in a specific year as compared to a decline by $0.80 \%$ (North Yemen in 1989).

Third, Powell (2012), among others, argues that the larger the military of a country, the less likely a coup will break out. Moreover, the higher the spending per soldier, the more content and professional is the military. Ultimately, this makes it more likely that the armed forces either respect the status quo (professionalism) or are content with current circumstances (lack of grievances), which decreases coup risk. Our findings largely support these claims: Soldier Quality and Military

25 In the appendix, we also discuss how the inclusion of these control variables to the analysis affects the naval forces' role in the probability of military coup. 
Personnel are negatively signed and significant, highlighting that coup risk drops by 30 percentage points and 2.7 percentage points, respectively, when increasing the respective item from its minimum to its maximum.

Fifth, Böhmelt and Pilster (2015) argue for a curvilinear relationship between counterbalancing and coup risk. Our results also shows that coup risk first decreases with higher levels of Counterbalancing, but then, after a tipping point of about two equally sized military organizations, increases. Hence, the lowest likelihood of a coup is given in highly polarized force-structure environments. Figure 4 graphs the probabilities of coup attempt for the values of Counterbalancing.

Figure 4 here

Finally, we included variables for temporal control in all our models as the likelihood of a coup attempt may be affected by earlier instances. While we omitted these controls from the presentation in the tables, Figure 5 summarizes our calculations of coup risk according to these temporal variables while holding all other items at their median. Clearly, the likelihood of a coup decreases over time, i.e., since the last coup event or the beginning of our observation period, but not necessarily in a linear fashion. That said, over a period of about 35 years, the risk of a coup roughly decreases by two thirds of the original baseline probability.

Figure 5 here

\section{Conclusion}

Do naval forces play a role for coups d'état? The previous literature largely neglected much of an influence. However, given several cases of naval participation in coups, we faced a puzzle that existing theoretical and empirical accounts could not address. We sought to shed light on this gap in 
the literatures on civil-military relations and force structure. Theoretically, we developed two hypotheses on the impact of naval forces on coup risk, which are based on the link between segments of the society and naval recruitment and bases. We eventually suggested that larger navies are more likely to be associated with coups. To emphasize it again, though, we have not argued that all naval troops will engage in coups at some point.

We quantitatively analyzed a sample of all states in 1971-2007 and found that larger navies tend to be linked to a higher coup risk. These results are robust across a series of model specifications and other robustness checks that we discuss in the appendix. We believe that these findings have a few implications for policymakers and public institutions. On one hand, given the strong association of naval forces and coups, the first and foremost advice to lower coup risk is not to abolish a navy completely, but to change the structure and composition of the naval forces - particularly the recruitment practices (Heginbotham 2004). On the other hand, convergence toward a balance of naval and the ground-combat armed forces seems misleading, at least from the perspective of stability and civil peace (Heginbotham 2004, 26, 45). Needless to say, however, that both recommendations, i.e., changing the composition of the naval forces and increasing the strength of the army, are processes with a longer time horizon, and they are likely to apply only to the relatively small number of states where an actual risk of a military coup does exist. They also do not account for the possible geo-political disadvantages a country may incur by weakening its naval forces.

Several avenues for further research exist. For example, our statistical models address associations between variables, not causation. We also studied the macro-level or net implications of a phenomenon in the context of coup attempts. To this end, we concentrated on a macro-level theoretical framework that attempts to explain events essentially consisting of a series of individual decisions. The empirical findings are, in principle, consistent with other arguments. ${ }^{26}$ While it is

26 That is, it may be that an increase in the size of the navy relative to the army could displease the latter due to an increase in the government's allocation of resources to the naval forces. Eventually, the army decides to launch a coup to try to take over the government and "gain a larger share of the pie" of available resources. However, again, the conditional hypothesis we develop in this article and empirically 
beyond the scope of this paper to successfully link macro-level theories to individual-level assessments of motives and preferences, a more detailed empirical analysis at the micro, i.e., individual, level seeking to address more thoroughly the underlying causal mechanisms could further improve our knowledge of naval forces and, generally, civil military relations and how are related to affect coup risk.

A more fine-grained testing of our argument might also focus on the interaction of strong naval forces, the strength of the urban middle class, and redistributive government policies, which may redistribute political and economic resources away from the urban middle class. This, however, requires new data on re-distributive policies that directly focus on the urban middle class and how it is affected by these policies.

Third, what is the relationship between navies and armies in coup attempts? Which force is most likely to lead these coup attempts? How often does the navy ally with the army, and how often are these two forces opposed to each-other? A more nuanced analysis along those lines seems essential, but we currently lack a sufficient amount of information to empirically study this. More, and particularly more fine-grained, data compilation is therefore important for furthering our understanding in this respect.

Finally, it remains to be seen whether the causal mechanisms we present can also be extended to a country's air force. Air forces tend to be more similar to navies than armies with regard to the weapons systems they employ; at the same time, air forces are often a smaller, younger, and less cohesive service than navies and they largely lack any ground-combat forces, which possibly limits their domestic political role. Eventually, research focusing on the entirety of a state's military forces would allow us to get a comprehensive understanding of civil-military relations and coup attempts. $^{27}$

examined above strongly points toward the link between segments of the society and naval recruitment and bases as a main explanation for why naval forces are positively associated with coup risk.

27 Having said that, we conducted a preliminary analysis using data on states' air forces, which we discuss in the appendix. 
Table 1. The Determinants of Coups d'état, 1971-2007 - Main Models

\begin{tabular}{lll}
\hline & Model 1 & Model 2 \\
\hline Navy Ratio & 2.551 & 2.296 \\
Military Regime & $(0.774)^{* * *}$ & $(0.742)^{* * *}$ \\
Change Military Expenditure & & 0.267 \\
& & $(0.230)$ \\
Soldier Quality & -0.069 & -0.089 \\
& $(0.185)$ & $(0.191)$ \\
Military Personnel & -0.328 & -0.365 \\
& $(0.093)^{* * *}$ & $(0.102)^{* * *}$ \\
Counterbalancing & -0.153 & -0.152 \\
& $(0.062)^{* *}$ & $(0.072)^{* *}$ \\
Counterbalancing ${ }^{2}$ & & -1.387 \\
Change GDP per capita & & $(0.717)^{*}$ \\
GDP per capita & & 0.356 \\
Instability & & $(0.177)^{* *}$ \\
Democracy & -3.580 & -3.477 \\
Autocracy & $(0.740)^{* * *}$ & $(0.766)^{* * *}$ \\
Constant & -0.186 & -0.159 \\
& $(0.106)^{*}$ & $(0.107)$ \\
Obs. & 0.078 & 0.078 \\
Wald $\chi^{2}$ & $(0.024)^{* * *}$ & $(0.025)^{* * *}$ \\
Prob $>\chi^{2}$ & -1.173 & -1.150 \\
& $(0.280)^{* * *}$ & $(0.293)^{* * *}$ \\
& -0.036 & -0.065 \\
& $(0.177)$ & $(0.183)$ \\
& 2.563 & 3.755 \\
& $(0.802)^{* * *}$ & $(1.100)^{* * *}$ \\
\hline & 4,438 & 4,408 \\
& -588.57 & -579.78 \\
& 259.03 & 263.88 \\
& 0.00 & 0.00 \\
\hline
\end{tabular}

Note: Table entries are coefficients; robust standard errors clustered on country in parentheses; variables for temporal correction included, but omitted from presentation.

* significant at 10 percent; $* *$ significant at 5 percent; $* * *$ significant at 1 percent (two-tailed) 
Table 2. Interactive Specification between Urban Concentration and Navy Ratio

\begin{tabular}{|c|c|}
\hline & Model 3 \\
\hline Navy Ratio & $\begin{array}{l}-5.019 \\
(2.317)^{* *}\end{array}$ \\
\hline Urban Concentration & $\begin{array}{l}-1.512 \\
(0.660)^{* *}\end{array}$ \\
\hline Navy Ratio * Urban Concentration & $\begin{array}{l}18.540 \\
(5.703)^{* * *}\end{array}$ \\
\hline Military Regime & $\begin{array}{c}0.174 \\
(0.257)\end{array}$ \\
\hline Change Military Expenditure & $\begin{array}{l}-0.049 \\
(0.188)\end{array}$ \\
\hline Soldier Quality & $\begin{array}{l}-0.390 \\
(0.118)^{* * *}\end{array}$ \\
\hline Military Personnel & $\begin{array}{l}-0.189 \\
(0.100)^{*}\end{array}$ \\
\hline Counterbalancing & $\begin{array}{l}-1.577 \\
(0.822)^{*}\end{array}$ \\
\hline Counterbalancing $^{2}$ & $\begin{array}{l}0.383 \\
(0.202)^{*}\end{array}$ \\
\hline Change GDP per capita & $\begin{array}{l}-3.624 \\
(0.933) * * *\end{array}$ \\
\hline GDP per capita & $\begin{array}{l}-0.171 \\
(0.123)\end{array}$ \\
\hline Instability & $\begin{array}{l}0.084 \\
(0.029) * * *\end{array}$ \\
\hline Democracy & $\begin{array}{l}-0.723 \\
(0.423)^{*}\end{array}$ \\
\hline Autocracy & $\begin{array}{l}-0.309 \\
(0.217)\end{array}$ \\
\hline Constant & $\begin{array}{l}5.183 \\
(1.264)^{* * *}\end{array}$ \\
\hline Obs. & 2,287 \\
\hline Log Pseudo Likelihood & -449.47 \\
\hline Wald $\chi^{2}$ & 158.98 \\
\hline Prob $>\chi^{2}$ & 0.00 \\
\hline
\end{tabular}

Note: Table entries are coefficients; robust standard errors clustered on country in parentheses; variables for temporal correction included, but omitted from presentation.

* significant at 10 percent; $* *$ significant at 5 percent; $* * *$ significant at 1 percent (two-tailed) 


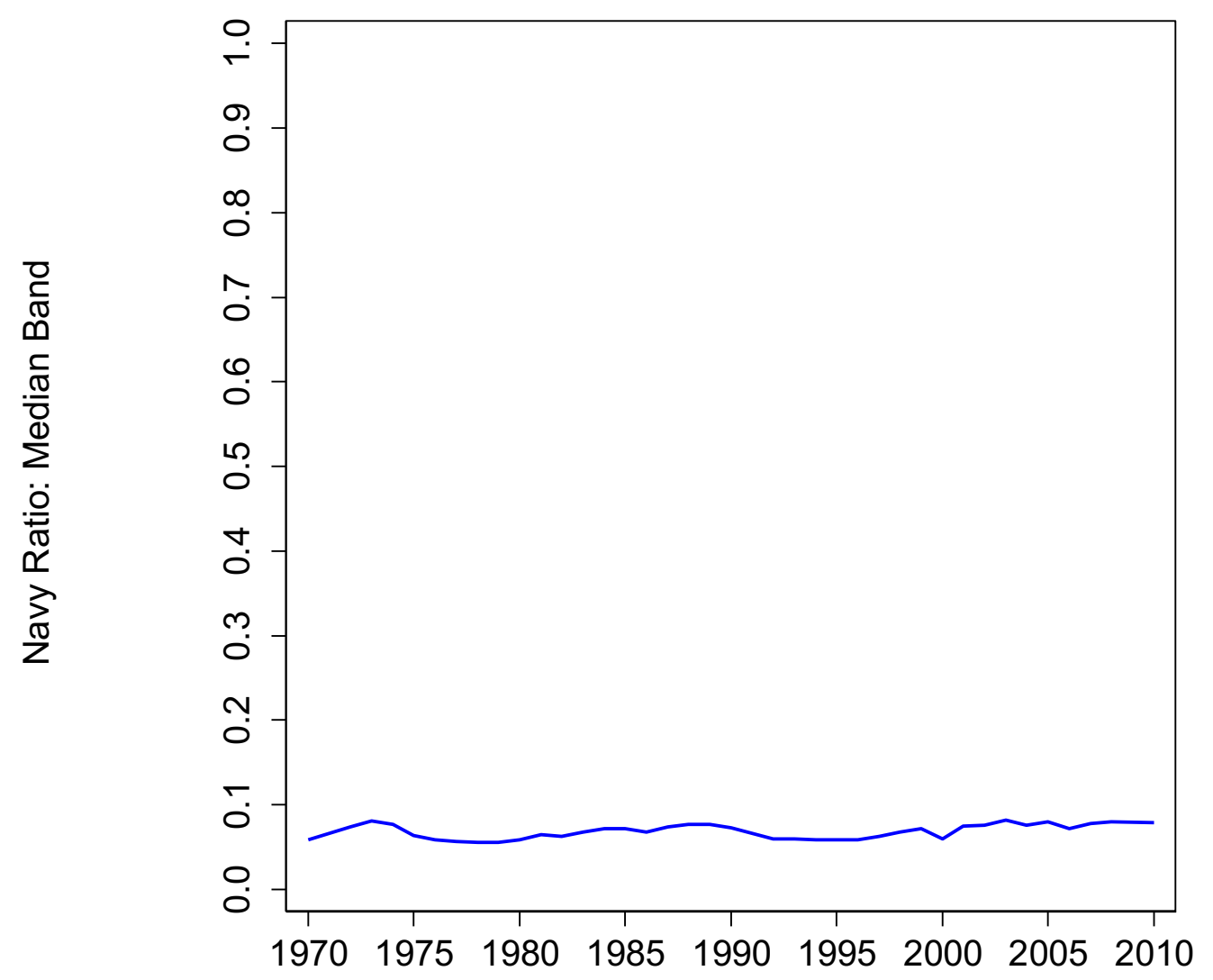

Figure 1. The Evolution of Naval Forces in Relation to Army Forces - Median Band Note: Graph displays median band of Navy Ratio in 1970-2007. 


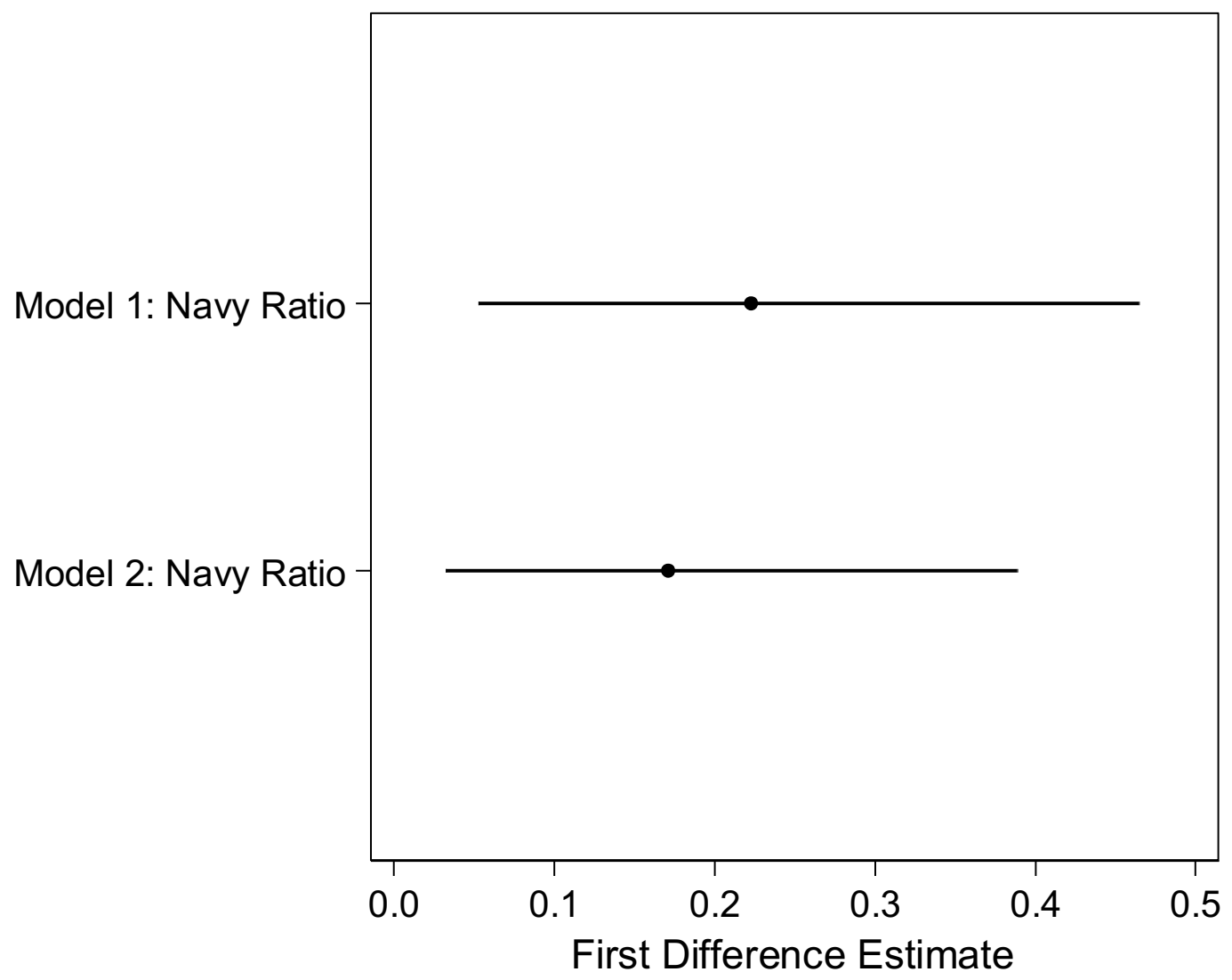

Figure 2. First Difference Estimates for Navy Ratio

Note: Graph displays point estimates and 90 percent confidence intervals (horizontal bars) for first differences. A first difference is the change in the probability that Coup Attempt $=1$ associated with a change from the minimum to the maximum value of Navy Ratio while holding all other covariates at their median. 


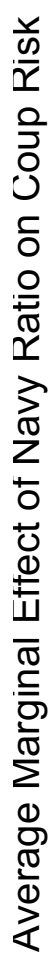

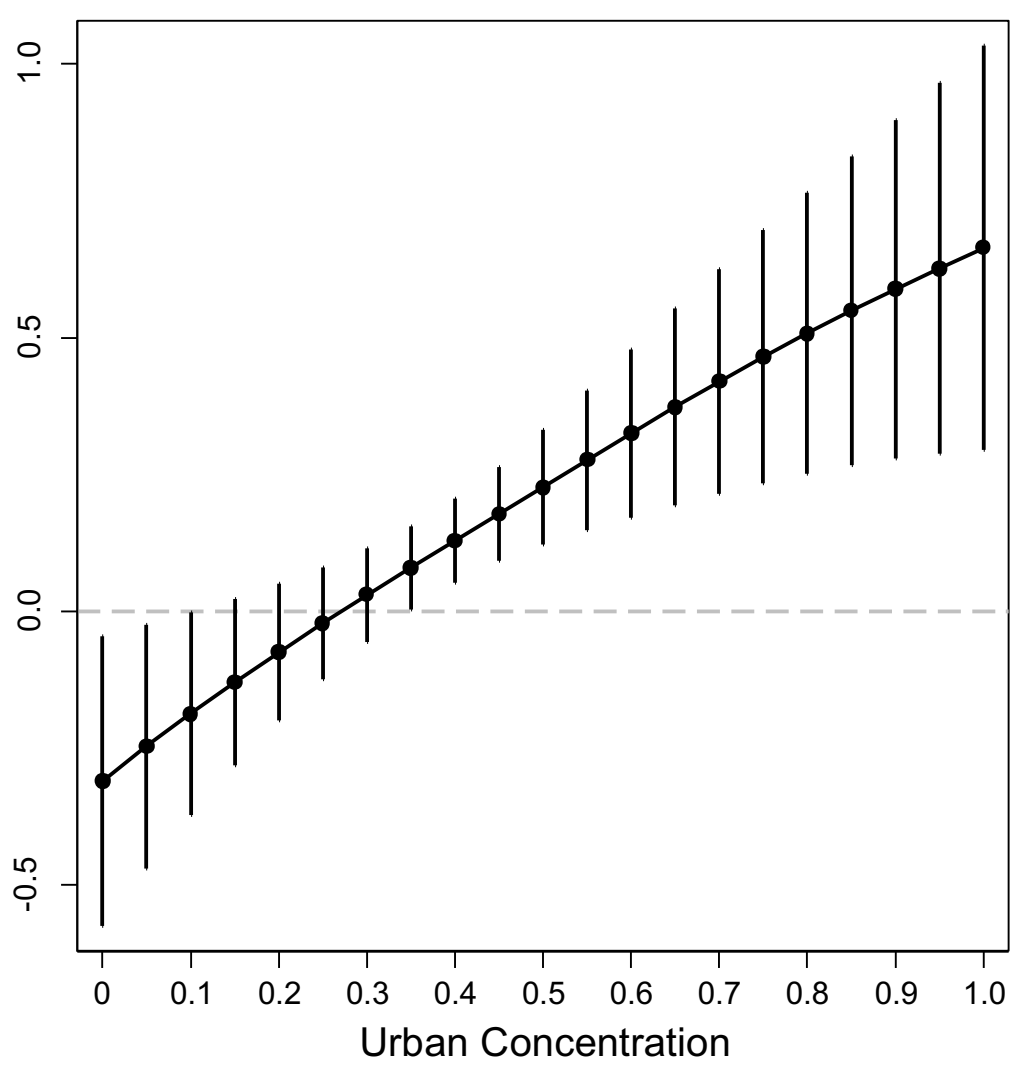

Figure 3. The Interaction between Navy Ratio and Urban Concentration

Note: Graph displays average marginal effects on the risk of a coup for an increase in Navy Ratio and conditional on Urban Concentration; vertical bars pertain to 90 percent confidence intervals; average marginal effect of 0 marked with dashed horizontal line. 


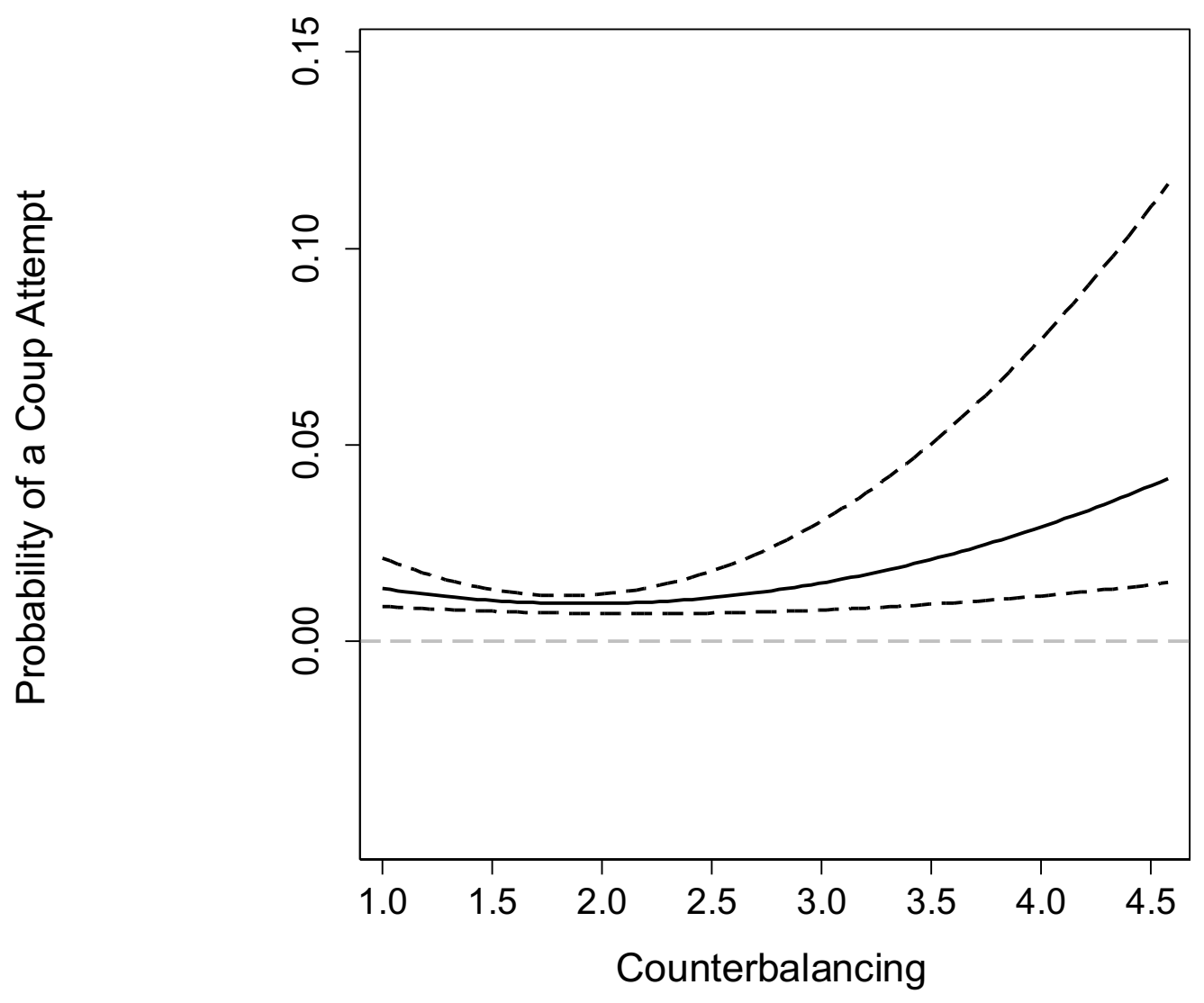

Figure 4. The Curvilinear Impact of Counterbalancing on Coup Risk

Note: Graph displays predicted probabilities for a coup attempt; dashed lines pertain to 90 percent confidence interval; predicted probability of 0 marked with dashed horizontal line. 


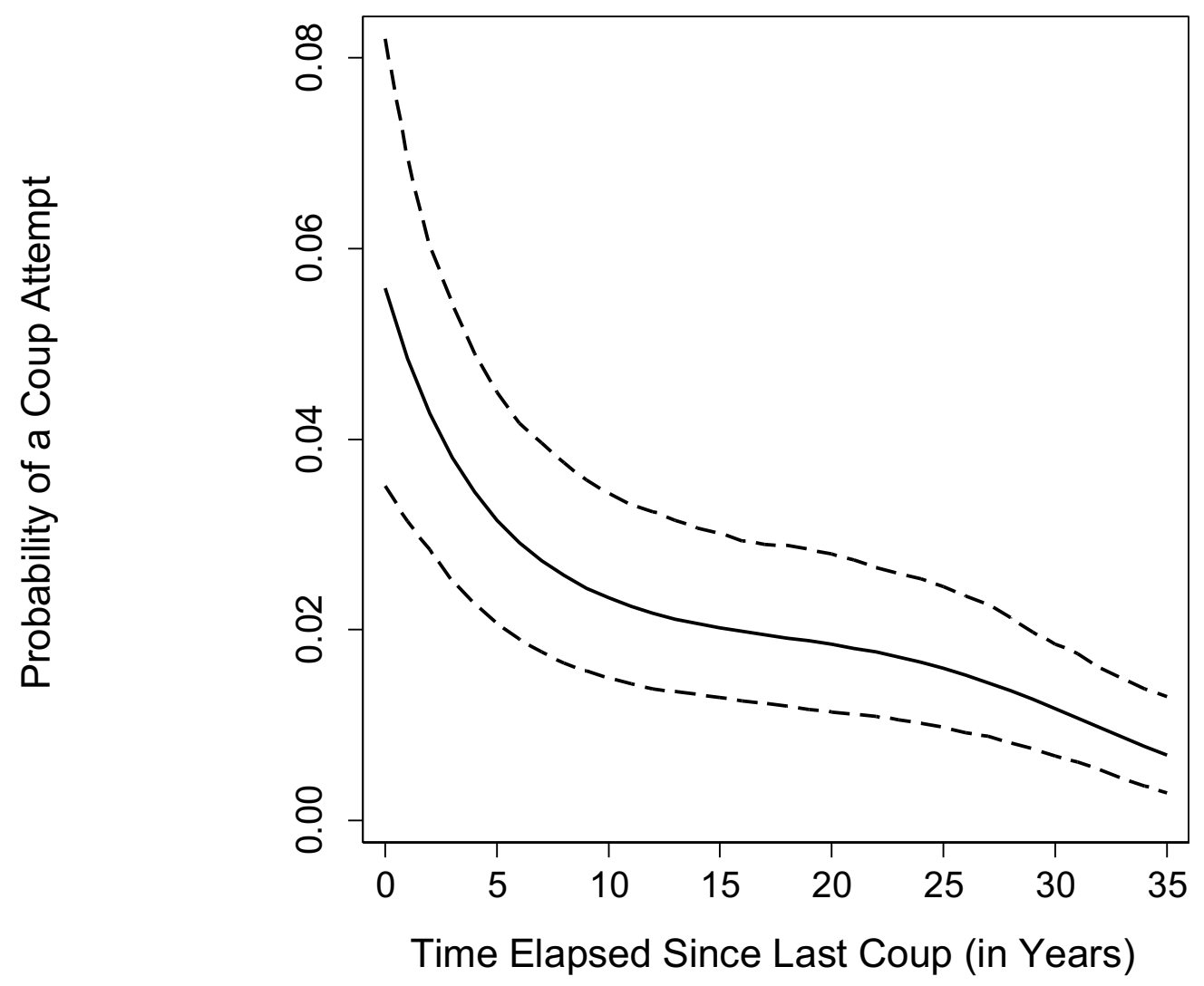

Figure 5. The Development of Coup Risk over Time

Note: Graph displays predicted probabilities for a coup attempt over time (time elapsed since the last coup attempt, if any); dashed lines pertain to 90 percent confidence interval. 


\section{References}

Allison, Simon. 2015. How the People of Burkina Faso Foiled a Military Coup. The Guardian. Available online at: http://www.theguardian.com/world/2015/sep/25/burkina-faso-foiled$\underline{\text { military-coup. }}$

Arbatli, Cemal Eren, and Ekim Arbatli. 2016. "External Threats and Political Survival: Can Dispute Involvement Deter Coup Attempts?" Conflict Management and Peace Science 33(2): 115-52.

Banks, Arthur. 2001. Cross-National Time-Series Data Archive. Binghamton, NY: Computer Systems Unlimited.

Banks, Arthur, and Kenneth Wilson. 2012. Cross-National Time-Series Data Archive. Jerusalem: Databanks Intl.

Beall, Jo, Tom Goodfellow, and Dennis Rodgers. 2013. "Cities and Conflict in Fragile States in the Developing World.” Urban Studies 50(15): 3065-83.

Beck, Nathaniel, Jonathan Katz, and Richard Tucker. 1998. "Taking Time Seriously: Time-Series Cross-Section Analysis with a Binary Dependent Variable.” American Journal of Political Science 42(4): 1260-88.

Beissinger, Henry W., Amaney Jamal, and Kevin Mazur. 2015. Who Participated in the Arab Spring? A Comparison of Egyptian and Tunisian Revolutions. Princeton University: Typescript. Available online at: http://www.princeton.edu/ mbeissin/beissinger.tunisiaegyptcoalitions.pdf.

Belkin, Aaron. 2005. United We Stand: Divide-And-Conquer Politics and the Logic of International Hostility. Albany, NY: State University of New York Press.

Belkin, Aaron, and Evan Schofer. 2003. "Toward a Structural Understanding of Coup Risk." Journal of Conflict Resolution 47(5): 594-620.

Böhmelt, Tobias, and Ulrich Pilster. 2015. “The Impact of Institutional Coup-Proofing on Coup Attempts and Coup Outcomes.” International Interactions 41(1): 158-82.

Brown, James. 1974. "The Military and Society in Greece.” European Journal of Sociology 15(2): 244-61. 
Brown, James. 1980. “Greek Civil-Military Relations: A Different Pattern.” Armed Forces \& Society 6(3): 389-413.

Bueno de Mesquita, Bruce, Alastair Smith, Randolph Siverson, and James Morrow. 2004. The Logic of Political Survival. Cambridge, MA: MIT Press.

Casper, Brett Allen, and Scott A. Tyson. 2014. "Popular Protest and Elite Coordination in a Coup d'état." Journal of Politics 76(2): 548-64.

Caverly, Jonathan, and Todd Sechser. 2016. "Military Technology and the Duration of Civil Conflict.” International Studies Quarterly: Forthcoming.

Cheibub, José Antonio, Jennifer Gandhi, and James Raymond Vreeland. 2010. "Democracy and Dictatorship Revisited." Public Choice 143(2-1): 67-101.

Chrisher, Brian, and Mark Souva. 2014. "Power at Sea: A Naval Power Dataset, 1865-2011." International Interactions 40(4): 602-29.

Decalo, Samuel. 1990. Coups and Army Rule in Africa: Motivations and Constraints. New Haven, CT: Yale University Press.

Ensalaco, Mark. 1999. Chile under Pinochet: Recovering the Truth. Pittsburgh, PA: University of Pennsylvania Press.

Feaver, Peter. 1992. “Command and Control in Emerging Nuclear Nations.” International Security 17(3): 160-87.

Feaver, Peter D. 1999. “Civil-Military Relations.” Annual Review of Political Science 2(1): 211-41.

Finer, Samuel E. 1988. The Man on the Horseback: The Role of the Military in Politics. London: Penguin.

Fordham, Benjamin. 1998. "The Politics of Threat Perception and the Use of Force: A Political Economy Model of U.S. Uses of Force, 1949-1994.” International Studies Quarterly 42(3): 56790.

Fordham, Benjamin. 2004. “A Very Sharp Sword: The Influence of Military Capabilities on American Decisions to Use Force.” Journal of Conflict Resolution 48(5): 632-56. 
Geddes, Barbara. 2003. Paradigms and Sand Castles: Theory Building and Research Design in Comparative Politics. Ann Arbor, MI: University of Michigan Press

Geddes, Barbara, Erica Frantz, and Joseph Wright. 2014a. “Autocratic Breakdown and Regime Transitions: A New Data Set.” Perspectives on Politics 12(2): 313-31.

Geddes, Barbara, Erica Frantz, and Joseph Wright. 2014b. "Military Rule." Annual Review of Political Science 17(1): 147-62.

Girod, Desha. 2015. "Reducing Postconflict Coup Risk: The Low Windfall Coup-Proofing Hypothesis." Conflict Management and Peace Science 32(2): 153-74.

Goldsworthy, David. 1980. "Civilian Control of the Military in Black Africa." African Affairs 80(318): 49-74.

Hadenius, Axel, and Jan Teorell. 2007. "Pathways from Authoritarianism." Journal of Democracy 18(1): 143-57.

Harkness, Kristen A. 2016. "The Ethnic Army and the State: Explaining Coup Traps and the Difficulties of Democratization in Africa.” Journal of Conflict Resolution 60(4): 587-616.

Heginbotham, Eric. 2002. "The Fall and Rise of Navies in East Asia: Military Organizations, Domestic Politics, and Grand Strategy.” International Security 27(2): 86-125.

Heginbotham, Eric. 2004. Crossed Swords: Divided Militaries and Politics in East Asia. Massachusetts Institute of Technology: PhD Dissertation.

Hibbs, Douglas A. 1973. Mass Political Violence: A Cross-National Causal Analysis. New York: John Wiley.

Hiroi, Taeko, and Sawa Omori. 2013. "Causes and Triggers of Coups d'état: An Event History Analysis." Politics and Policy 41(1): 39-64.

Hobsbawm, Eric. 1973. Revolutionaries: Contemporary Essays. New York: Pantheon Books Huntington, Samuel. 1968. Political Order in Changing Societies. New Haven, CT: Yale University Press. 
International Institute for Strategic Studies. 1970-2014. The Military Balance. London: International Institute for Strategic Studies.

Janowitz, Morris. 1964. The Military in the Political Development of New Nations: An Essay in Comparative Analysis. Chicago, IL: University of Chicago Press.

Janowitz, Morris. 1977. Military Institutions and Coercion in the Developing Nations. Chicago, IL: University of Chicago Press.

King, Gary, Michael Tomz, and Jason Wittenberg. 2000. "Making the Most of Statistical Analyses: Improving Interpretation and Presentation.” American Journal of Political Science 44(2): 34761.

Lindberg, Staffan, and John Clark. 2008. "Does Democratization Reduce the Risk of Military Interventions in Politics in Africa?" Democratization 15(1): 86-105.

Luttwak, Edward. 1968. Coup d'état: A Practical Handbook. London: Penguin.

Lyall, Jason, and Isaiah Wilson. 2009. "Rage Against the Machines: Explaining Outcomes in Counterinsurgency Wars.” International Organization 63(1): 67-106.

Magaloni, Beatriz, and Jeremy Wallace. 2008. Citizen Loyalty, Mass Protest, and Authoritarian Survival. Stanford University: Typescript.

Mahan, Alfred Thayer. 1890. The Influence of Sea Power upon History, 1660-1783. Boston, MA: Little, Brown, and Company.

Marshall, Monty, and Keith Jaggers. (2004) POLITY IV Project: Political Regime Characteristics and Transitions, 1800-2004. Dataset User's Manual. College Park, MD: University of Maryland.

McMahon, Blake, and Branislav Slantchev. 2015 “The Guardianship Dilemma: Regime Security through and from the Armed Forces." American Political Science Review 109(2): 297-313.

Modelski, George, and William Thompson. 1988. Seapower in Global Politics, 1994-1993. Seattle, WA: University of Washington Press. 
Moncada, Eduardo. 2013. "The Politics of Urban Violence: Challenges for Development in the Global South.” Studies in Comparative International Development 48(3): 217-39.

Nordlinger, Eric. 1977. Soldiers in Politics: Military Coups and Governments. Prentice-Hall, NJ: Englewood Cliffs.

Perlmutter, Amos. 1969. "The Praetorian State and the Praetorian Army." Comparative Politics 1(3): 382-404.

Pilster, Ulrich, and Tobias Böhmelt. 2011. "Coup-Proofing and Military Effectiveness in Interstate Wars, 1967-99." Conflict Management and Peace Science 28(4): 331-50.

Pilster, Ulrich, and Tobias Böhmelt. 2012. “Do Democracies Engage Less in Coup-Proofing? On the Relationship between Regime Type and Civil-Military Relations." Foreign Policy Analysis $8(4): 355-72$.

Piplani, Varun, and Caitlin Talmadge. 2016. "When War Helps Civil-Military Relations Prolonged Interstate Conflict and the Reduced Risk of Coups." Journal of Conflict Resolution 60(8): 1368-94.

Porch, Douglas. 1977. The Portuguese Armed Forces and the Revolution. London: Croom Helm.

Powell, Jonathan. 2012. "Determinants of the Attempting and Outcome of Coups d'état." Journal of Conflict Resolution 56(6): 1017-40.

Powell, Jonathan. 2014. "Regime Vulnerability and the Diversionary Threat of Force." Journal of Conflict Resolution 58(1): 169-96.

Powell, Jonathan, and Clayton Thyne. 2011. “Global Instances of Coups from 1950-2010: A New Dataset." Journal of Peace Research 48(2): 249-59.

Quinlivan, James. 1999. Coup-Proofing: Its Practice and Consequences in the Middle East. International Security 24(2): 131-165.

Reiter, Dan. 2001. “Why NATO Enlargement Does Not Spread Democracy.” International Security 25(4): 41-67. 
Roessler, Philip. 2011. "The Enemy Within: Personal Rule, Coups, and Civil War in Africa." World Politics 63(2): 300-46.

Ruby, Tomislav, and Douglas Gibler. 2010. "US Professional Military Education and Democratization Abroad.” European Journal of International Relations 16(3): 339-64.

Saleyhan, Idean, and Kristian Skrede Gleditsch. 2006. "Refugees and the Spread of Civil War." International Organization 60(2): 335-66.

Savage, Jesse, and Jonathan Caverley. 2015. Foreign Military Training and Coup Propensity. University of Melbourne: Typescript.

Scheina, Robert. 2003. Latin America's Wars. Washington, DC: Brassey's, Inc.

Sechser, Todd, and Elizabeth Saunders. 2010. "The Army You Have: The Determinants of Military Mechanization, 1979-2001.” International Studies Quarterly 54(2): 481-511.

Singh, Naunihal. 2014. Seizing Power: The Strategic Logic of Military Coups. Baltimore, MD: Johns Hopkins University Press.

Spooner, Mary. 1999. Soldiers in a Narrow Land - The Pinochet Regime in Chile. Berkeley, CA: University of California Press.

Staniland, Paul. 2010. "Cities on Fire: Social Mobilization, State Policy, and Urban Insurgency." Comparative Political Studies 43(12): 1623-49.

Stepan, Alfred. 1971. The Military in Politics: Changing Patterns in Brazil. Princeton, NJ: Princeton University Press.

Svolik, Milan. 2012. The Politics of Authoritarian Rule. Cambridge: Cambridge University Press. Teichman, Judith. 2015. "The Role of the Middle Class in Distributional Outcomes: Chile and South Korea." Studies in Comparative International Development 50(1): 1-21.

Thompson, William. 1973. Grievances of Military Coup-Makers. London: Sage.

Thompson, William. 1976. “Organizational Cohesion and Military Coup Outcomes.” Comparative Political Studies 9(3): 255-76. 
Thyne, Clayton. 2010. "Supporter of Stability or Agent of Agitation? The Effect of United States Foreign Policy on Coups in Latin America, 1960-1999." Journal of Peace Research 47(4): 1-13. Toft, Monica Duffy. 2003. The Geography of Ethnic Violence: Identity, Interests, and the Indivisibility of Territory. Princeton, NJ: Princeton University Press.

Trinkunas, Harold. 2006. Crafting Civilian Control of the Military in Venezuela: A Comparative Perspective: A Comparative Perspective. Chapel Hill, NC: University of North Carolina Press.

Unaldi, Serhat. 2014. Thailand: A Coup, the Crown, and Two Middle Classes. The Diplomat. Available online at: http://thediplomat.com/2014/05/thailand-a-coup-the-crown-and-two-middle$\underline{\text { classes. }}$

Uyar, Mesut, and Edward J. Erickson. 2009. A Military History of the Ottomans. Santa Barbara, CA: ABC-CLIO.

Urdal, Henrik, and Kristian Hoelscher. 2012. "Explaining Urban Social Disorder and Violence: An Empirical Study of Event Data from Asian and Sub-Saharan African Cities.” International Interactions 38(4): 512-28.

Wallace, Jeremy. 2013. "Cities, Redistribution, and Authoritarian Regime Survival.” Journal of Politics 75(3): 632-45.

Wallace, Jeremy. 2014. Cities and Stability: Urbanization, Redistribution, and Authoritarian Resilience in China. Oxford: Oxford University Press.

Welch, Claude. 1970. Soldiers and State in Africa. Evanston, IL: Northwestern University Press.

Wintrobe, Ronald. 1998. Political Economy of Dictatorship. Cambridge: Cambridge University Press.

Zipf, George. 1941. National Unity and Disunity. The Nation as a Bio-Social Organism. Bloomington, IN: Principia Press.

Zürcher, Erik. 2004. Turkey: A Modern History. London: I. B. Tauris. 